Aquaculture

January 2015, Volume 435, Pages 361-370

http://dx.doi.org/10.1016/j.aquaculture.2014.10.014

http://archimer.ifremer.fr/doc/00216/32745/

(c) 2014 Elsevier B.V. All rights reserved.

\title{
Influence of grafter skill and season on cultured pearl shape, circles and rejects in Pinctada margaritifera aquaculture in Mangareva lagoon
}

\author{
Ky Chin-Long ${ }^{1,{ }^{*}}$, Nakasai Seiji ${ }^{2}$, Molinari Nicolas ${ }^{3}$, Devaux Dominique ${ }^{4}$
}

\author{
${ }^{1}$ Ifremer, UMR 241, EIO, Labex Corail, Centre du Pacifique, BP 7004, 98719 Taravao, Tahiti - \\ Polynésie Française \\ ${ }^{2}$ SCA Regahiga Pearls, BP 48, 98755Rikitea Gambier - Polynésie Française \\ ${ }^{3}$ UMR729, INRA, Montpellier SupAgro, 2 Place Viala, 34060 Montpellier, France \\ ${ }^{4}$ Groupement d'Intérêt Economique Poe O Rikitea, BP 176, 98755 Rikitea Gambier- Polynésie \\ Française
}

* Corresponding author, email address : chinky@ifremer.fr

\begin{abstract}
:
Cultured pearls quality produced by the mollusc Pinctada margaritifera var. cumingi is determined by a panel of criteria, of which shape is one of the most relevant. Cultured pearls with round and semi-round (RS) shapes are the most valuable. Decreasing the proportion of other pearl shapes (OT: baroque, button, drop, oval), and especially the circled pearls (CL) and rejects (rebuts: RT), is an important challenge for the pearl industry. The present study examined the effect of grafter skill and season of graft on the variation in proportions of CL, RS, OT and RT cultured pearl shape categories in a monosite culture (Mangareva island lagoon). Six large-scale grafting experiments, carried out in the same way as commercial grafting sessions, were made by seventeen experienced grafters over three seasons. After two years of culture, a total of 42,575 cultured pearls were harvested and sorted into shape categories. This study is the first to apply large-scale traceability to effects of individual grafter skill on cultured pearl shape in P. margaritifera. Grafter effects were clearly demonstrated on the proportions 1) of $\mathrm{CL}$ and $\mathrm{RS}, 2$ ), to a in a lesser extent, of OT and RT, but 3) were low, affecting only a few percent of the overall means. For a high quality cultured pearl production, grafter effect could reduce $\mathrm{CL}$ rate by $7 \%$ and increase $\mathrm{RS}$ rate by $4 \%$. In addition, the results indicate a significantly indirect influence of grafting season on shape class proportions, as these differ in autumn grafts, CL ($12 \%)$, RS (+ $13 \%)$ and OT (+ $24 \%)$, in comparison to winter and spring. Possible implications of "oyster" physiological reproductive status are discussed, as the difference in grafting season corresponds to differences in maturity of the recipient "oysters". Rates of RT were only increased $(+14 \%)$ during the seasons when the lagoon water temperature was the coldest (winter) and the warmest (transition to summer).
\end{abstract}

Highlights 
- Grafter skill impact cultured pearl shape in P. margaritifera. Season of graft influence also pearl shape proportion. Season of graft effect more pearl shape than grafter skill. Physiological status of oysters in relation to environment influence pearl shape

Keywords : Pinctada margaritifera, cultured pearl, grafter skill, pearl shapes, circled pearls, round/ semi round pearls, rebut pearls, grafting season 


\section{Introduction}

The mollusc Pinctada margaritifera var. cumingi is a species of great economic importance in French Polynesia. The cultured pearl industry associated represents the second most important economic income of French Polynesia, just below tourism, with an export value of nearly 65 million euros (Wane, 2013). At its peak of development in the year 2000, the French Polynesian pearl industry employed 7,000 people (Murzyniec-Laurendeau, 2002). However, the average price (at export) of cultured pearls in French Polynesia has fallen by a factor of four in the past decade, from 16 euros to 4 euros per unit (Talvard, 2011), a depreciation that is partly the result of diminishing quality in the output of many pearl farms. Indeed, both the average size and average quality of these cultured pearls are lower than a decade ago (Blay et al., 2014). Today, pearl production is conducted on 25 atolls and islands, employing nearly 5,000 people on 487 farms (Ky et al., 2014a). Statistical data from the 9th Cooperative Tahiti Auction (March 2014) revealed that the average price of a cultured pearl is presently close to 10.5 euros.

Increase of cultured pearl quality is the key to pearl farm viability and one of the biggest challenges for research and development. The greater the proportion of high-quality cultured pearls in a harvest, the more likely a farm will be profitable. Several approaches aimed at improving pearl quality has been study : physiology (Cochennec et al., 2006), genetic (McGinty et al., 2010 and 201), genomic (McGinty et al., 2012; Joubert et al., 2014), management (Cartier et al., 2012). Le Pennec et al. (2010) estimated that for 2,000 grafted pearl oysters, only 3\% will yield grade A quality cultured pearls (according to the official AD classification: see Journal Officiel $2001 \mathrm{n}^{\circ} 30,26$ July 2001); improving this rate to 4\% would considerably increase farmers' incomes. Shape is one of several factors that go into determining pearl quality, and therefore value. In the cultured pearl farming process, a grafting operation must be performed, which requires a donor pearl oyster, a recipient pearl oyster and a skilled technician to perform the surgery (Ky et al., 2014a). The recipient oyster is operated upon and a nucleus (made of mollusc shell or synthetic material) inserted, together with a piece of donor mantle tissue (the "saibo", also known as the graft), into a part of the pearl oyster called the pearl pocket (first graft operation). Whereas the donor oyster (which is sacrificed) is selected for the quality of its mantle, the recipient oyster is chosen for its vigour (Haws, 2002; Ky et al., 2014a). In general, round and semi-round (RS) cultured pearls are the most valuable, in comparison to other common shapes (OT) such as button, drop, baroque or 
oval, which are less valuable (for the same quality). In addition to these common shapes, some cultured pearls develop concentric rings or grooves visible on the surface. These cultured pearls are known as circled. This adjective can be attached to the primary shape in order to more fully describe the cultured pearl, such as "circled round" or "ringed oval" (CL). All pearl farmers aim to harvest more RS pearl, with less CL and reject (also known as "rebut" pearls: RT) pearls (which are destroyed, due to their very low quality). In fact, the average price between the different shapes for RS, OT and CL are respectively: 9.2, 4.2 and 1.1 euros per grams.

Cultured pearl quality traits are influenced by a number of highly variable factors, including genetics, the environment and their interaction, growth rate, husbandry, surgical technique and hygiene (Southgate and Lucas, 2008). Biological mechanisms influencing rates of RS, CL, RT and OT (without circles) cultured pearl shapes are complex and only a few studies have focussed on the determining factors of these shapes in P. margaritifera. Using oysters produced in the hatchery system, Ky et al (2013) revealed that the presence of circled pearls was not influenced by donor family. In contrast, selection of donor oysters from the wild (Tayale et al., 2012) or produced in the hatchery (Ky et al, 2013) would be effective in increasing the proportion of round and semi-round pearls and decreasing the number of rejects. A recent study revealed a significant phenotypic correlation between cultured pearl quality (grade) and shape in P. margaritifera (Ky et al., 2014b). The A-B grade pearl classes had the lowest number of circled pearls $(15 \%)$ and the maximum number of round shaped pearls $(45 \%)$. In contrast, the reject class (RT) had the greatest number of circled pearls $(35 \%)$ and the maximum with a baroque shape (nearly $60 \%$ ).

The present study was designed to show us how grafter skill and/or the month of grafting (season effects) could affect the rate of production of CL, RS, OT and RT cultured pearls, and thus help to build better management strategies for cultured pearl production on each farm, which could involve investment in grafter skill improvement or adapting the yearly schedule for the graft season to the most favourable period. 


\section{Materials and methods}

\subsection{Animals}

Wild saibo donor and recipient Pinctada margaritifera were collected as spat in the lagoon of Mangareva island (Gambier Archipelago, French Polynesia) during the main reproductive season of 2008 (November and December). Rearing systems of young to mature oysters were described in Ky et al (2014a). After the grafting operation, these pearl oysters were attached to chaplets and protected by nets to reduce predation and were regularly cleaned.

\subsection{Grafting operation and experimental design}

In the first stage of grafting, a grafter selects a donor pearl oyster from a set of healthy animals with colourful inner shells, based on the following criteria: colour of the visceral mass and gills, shell size and appearance, and muscle resistance when opening the shells. The epithelial cells required for the grafting procedure are excised from its mantle. Small strips of epithelium are prepared before being transplanted into the recipient oysters; the grafts themselves are pieces measuring approximately $4 \mathrm{~mm}^{2}$. In the second stage of grafting, each receiving mollusc is selected based on its visible health status. The grafter cuts out a hollow in the recipient "oyster" gonad in which they then place the nucleus and graft. The nuclei used were imported from Japan: 6.6 mm nucleus (2.2 BU Yellow Bio FNC- $\alpha$, Imai Seikaku Co., Japan).The whole operation takes approximately 1 minute (Ky et al, 2014a).

Seventeen different experienced grafters (referred to by their initials: G, UM, MC, TC, EY, MD, MH, MM, GH, TARA, MAI, ME, AIU, F, TT, POE and MT) were employed for the grafting experiments in 2010. Six graft experiments named by number 4, 7, 8, 9, 10 and 11 were targeted during the respectively corresponding months: April, July, August, September, October and November. The corresponding pearls were harvested during 2012, after 24 months of culture. Figure 1 illustrates the design of the grafting experiment, showing the periods of subsequent culture and timing of pearl harvest. During these graft experiments (year 2010), a total of 42,575 pearls were harvested. Traceability of oysters grafted by each of the technicians was maintained by using a specific combination of coloured cords attached to the rearing chaplets.

\subsection{Sorting cultured pearls into shape categories}


The cultured pearls were extracted from the oysters and directly put into compartmented boxes identified for each of the grafters and containing marine water. At the end of the working day, the harvested cultured pearls were cleaned in hot soapy freshwater for 30 minutes (machine washing) and then dried using towels. The pearls were then visually (without loupe) sorted by one operator into four classes (Fig. 2): 1) "CL" for the presence of circle(s), shown by regular streaks or concave rings on the pearl whatever its shape category; 2) "RS", for round or semi-round shapes (diameter variation $<5 \%$ ); 3 ) "OT" for other shapes, without any circles, corresponding to baroque, button, drop or oval shapes, and 4) "RT", for the reject pearls; which have too many defects to be graded and will consequently be discarded and ultimately destroyed (Journal Officiel 2001 n³ 30, 26 July 2001).

\subsection{Statistical analysis}

Because CL, RS, OT and RT cultured pearl rates were evaluated for every month when grafting was performed (6 experiments), each grafter was evaluated several times (repeated measures). Thus, outcome variables were compared by univariate analysis using a linear mixed-effects model for repeated measures, making it possible to take into account repeated measures as random variables. This model is particularly useful in settings where repeated measurements are taken on the same statistical units. Then, this model was used to take into account grafter effect. Multivariate analysis was then performed using a linear mixed-effects model for repeated measures. The estimated fixed effects are given and tested against a null effect ( $p$ value). A test for association between paired samples was used to test Pearson's correlation coefficient. Linear regression was performed to define the association between quantitative variables. Variables were selected if the $p$ value was less than 0.20 in the univariate analysis, and a stepwise procedure was used to select the final model. A $p$ value of $\leq .05$ was considered statistically significant. Data were analysed using the $\mathrm{R}$ software (Copyright (C) 2014 The R Foundation for Statistical Computing) version 3.1 .0 (2014-01-10). 


\section{Results}

A total of 42,575 cultured pearls were harvested in 2012, after a period of 24 months of culture, over the 6 graft experiments conducted with the seventeen different grafters in 2010. The numbers and percentages of different cultured pearl shapes (in the 2012 harvest as a whole) were as follows: CL (circled) 22,620 (53.1\%); RS (round/semi-round) 12,107 (28.5\%); OT (other shapes) 5,717 (13.4\%); and RT (rejects) 2,131 (5.0\%). Among the graft experiments and individual grafters, the percentages of CL cultured pearls ranged from 42.1 to $66.3 \%$ (Table 1), RS pearls ranged from 17.9 to $39.5 \%$ (Table 2), OT pearl shapes ranged from $5.7 \%$ to $22.8 \%$ (Table 3 ) and RT from 2.5 to $13.2 \%$ (Table 4 ).

\section{Grafter effects}

Figure 3 illustrates the percentages of the different pearl shape classes obtained by each of the grafters.

Inter-grafter comparison revealed the existence of a grafter effect on CL cultured pearl production rate. The work of grafters MH $(p=0.01)$ and MM $(p=0.02)$ showed a significantly lower amount of CL pearls compared with the work of the other grafters (Figure 4a): $\mathrm{MH}$ and MM obtained $49.6 \% \mathrm{CL}$ on average (value obtained by considering all the experiment made by $\mathrm{MH}$ and MM - Table 1), which represented 7\% less than the overall mean. In contrast, the work of grafters TARA $(p<0.0001)$ and TC $(p=0.001)$ showed significantly higher amount of CL pearls compared with the work of the other grafters (Figure 4a): TARA and TC obtained $61 \% \mathrm{CL}$ on average (value obtained by considering all the experiment made by TARA and TC - Table 1), which represented $15 \%$ more than the overall mean.

Inter-grafter comparison revealed a grafter effect on RS cultured pearl production rate. The work of grafters $\mathrm{G}(p=0.001), \mathrm{MM}(p=0.01)$ and MT $(p=0.01)$ showed a significantly higher rates of RS rates compared with the work of the other grafters (Figure 4b). The three grafters G, MM and MT obtained an average of 32\% RS (Table 2), which represented nearly $4 \%$ more RS pearl than the overall mean (28.5\% of RS). In contrast, the work of grafters ME $(p=0.03)$, TARA $(p<0.0001)$, TC $(p<0.0001)$, and UM $(p=0.01)$ showed significantly lower percentages of round and semi-round shapes the work of the other grafters (Figure $4 \mathrm{~b}$ ). The four grafters ME, TARA, TC and UM obtained 23\% RS pearls on average (Table 2), which is nearly $5 \%$ less than the overall mean. 
Inter-grafter comparison revealed the existence of a grafter effect on the rate of production of OT cultured pearls. The work of grafters GH $(p=0.03)$ and $\mathrm{MH}(p=0.03)$ showed significantly higher amounts of other pearl shapes compared with the work of the other grafters (Figure 4c). The two grafters GH and MH reveals 17\% (Table 3) of OT cultured pearl rate, which represented $4 \%$ more than the overall mean $(13.4 \%)$.

Inter-grafter comparison showed no significant effect $(p>0.05)$ for RT cultured pearl production rate, except for grafter POE ( $p=0.001$ ) (Figure 4d) who obtained 8.5\% RT pearls (Table 4), representing nearly $3.5 \%$ more RT than the overall mean (5\%).

\section{Month of graft / seasonal effects}

The average rate of CL cultured pearls produced was $54.1 \%$, with rates varying from $48.4 \%$ to $58.1 \%$ among the six graft experiments (Table 1). In the same period, the RS pearls represented $27.9 \%$ on average, with minimum and maximum values of $25.9 \%$ and $31.4 \%$, respectively (Table 2). For the OT pearl shape, the average percentage was $12.9 \%$, with minimum and maximum values of $10.2 \%$ and $16.0 \%$, respectively (Table 3 ). The RT percentage was $5.1 \%$ and varied from $4.3 \%$ to $6.2 \%$ (Table 4 ).

Comparison of the graft experiments done in different months revealed a very highly significant difference in the amounts of CL, RS and OT cultured pearls $(p<0.001)$ for the month 4 experiment (Figure 5a, $5 \mathrm{~b}$ and $5 \mathrm{c}$ ). The CL rate minimum for the month 4 experiment and represented nearly $12 \%$ less CL than the overall mean. In contrast, the percentages of RS and OT rates were maximal in month 4 and represented nearly $13 \%$ and $24 \%$ more than the total mean. For RT pearls rates, experiments in months $8(p=0.002), 9(p$ $<0.001)$ and $11(p=0.016)$ produced significantly higher rate than in the other months (Figure 5d). Indeed, experimental grafts in months 8, 9 and 11 produced the most RT, with $5.8 \%$ on average, representing nearly $14 \%$ more RT than the overall mean.

A very highly significant negative correlation was found between the numbers of RS and CL cultured pearls produced $\left(\rho=-0.80, p<10^{-16}\right)$, with a linear regression between RS and CL rates for each grafter-experiment combination $\left(\mathrm{R}^{2}=0.63, p=1.310^{-15}\right)$. 


\section{Discussion}

This study is the first large scale analysis of its kind on the effect of grafter skill and grafting month on the relative percentage of different pearl shapes in P. margaritifera. Our results are based on a very large number of harvested samples $(42,575$ pearls) and reliable traceability of each of the seventeen grafters employed.

For CL pearls, $53.1 \%$ were found, which was up to two-fold more important than the 23\% found in Murzyniec-Laurendeau studies (2002) and in a more recent study (Ky et al 2013), made both in Tuamotu archipelago. In addition, the average rate of RS pearls was $28.5 \%$, which was considerably lower than the mean value found in a smaller experimental graft made by a single professional grafter, where $47 \%$ RS pearls were obtained (for 874 harvested pearls) (Ky et al. 2013). The maximum percentage of RS found here, at 39.5\%, was also lower than in this previous example. For RT pearls (poor quality and destroyed), 5\% were found, which was consistent with the results of Tayale et al (2012) for the minimum value (2.5\%) and Ky et al (2013) for the maximum value (13.2\%). Environmental parameters may be one of the factors that play a key role in CL and RS pearl formation. In particular, there is a difference in environmental culture conditions between atoll lagoons and around islands. Island lagoons are characterized by relatively high suspended particulate matter (accentuated during rainy periods), whereas atoll lagoons are characterized by oligotrophic waters with low turbidity. By contrast, the island lagoon in the present study does not appear to have impacted RT rate (as for the other shape classes). This suggests that RT rate is probably defined during the earlier stages of pearl formation, rather than over the whole culture process, as is probably the case for CL, RS and OT shapes.

\section{Grafter effects}

The influence of four of the seventeen grafters on CL shape was evident, while taking into account the grafting month (seasonal effect) in the statistical analysis. Although significant, the effects of the skill of these four grafters was not great in magnitude, with two of them increasing harvest value by reducing CL rate $(-7 \%)$ and two others decreasing harvest value by increasing this number $(+15 \%)$. For RS rate, seven of the seventeen grafters had significantly different results from the ten others, with three and four grafters showing higher (+4\%) and lower (-5\%) RS rate, respectively, in comparison to the total harvest mean. Once again, the grafter effect was significant, but relatively "minimal" to the generally held opinion that the skill level of an experienced technician has a large effect on the production of RS shape (Nava et al., 2000). The same tendency were found in a lesser degree, for the 
percentage of OT shape: only two of the seventeen technicians obtained a significantly higher $(+4 \%)$ amount of this shape in comparison with the overall mean. The grafter skill effect on RT rate was also minimal, as only the work of one of the seventeen grafters caused a difference: an increase of $+3.5 \%$ RT. This grafter has only used 7 donor oysters $(217$ pearls harvested), and thus the results obtained may include a correlated genetic donor effect for RT pearl production (Tayale et al, 2012; Ky et al, 2013). In addition, correct post-operative care minimizes expulsion of nuclei soon after implantation (Ky et al., 2014a) and reduces the occurrence of abnormal pearls (Wada, 1999; Akamatsu, 2003).

As for other traits affected by grafter skill in P. margaritifera (Ky et al, 2014a), the position of both saibo and nucleus implanted in a particular area of the oyster pearl pocket, may affect the frequency of CL and RS rates. Indeed, the technicians operated oysters of the same geographic origin, on the same pearl farm, under virtually the same conditions, with the same degree of hygiene, but their work still demonstrated significant differences in terms of CL and RS rates. In fact, the formation of RT pearls, as well as pearls with deformities, is the result of a physiological reaction of the host oyster to the implantation (Ogimura et al, 2012). The pearl presenting "tail" were produced by a bad or lack of healing of the incision made by the technician during the grafting process. The corresponding harvested cultured pearl digressed from the spherical pearl and then tend to produce OT shape (Norton et al, 2000).

The pearl's position within the mollusc plays a role in determining its shape. If the pearl develops against the shell, for example, it will become more flattened on that side. An "extreme" case is illustrated by a recent new development in pearl production involving the use of organic and baroque shell nuclei for beaded baroque sample production (Cartier and Krzemnicki, 2013). Due to the pearl sac expansion, it is difficult to produce RS and CL samples using this technique. This new development may also shed more light on the formation mechanism of RS and CL pearls and provide insight on the relationship between the pearl sac and nucleus. Ito (2009) investigated formation mechanisms of CL pearls and disagreed with the widely held idea that they result from nucleus rotation in the pearl sac (see also Caseiro, 1993). Ito argued that if this were the case, nonlinear patterns would be found on CL pearls, whereas a study of 4,011 samples found no evidence for these (Ito 2011), and proposed a mantle cell proliferation mechanism for CL shape formation, that take its origin through defect on the pearl surface (Gauthier et al., 2014).This proliferation mechanism, which is under genetic control, could be associated with the significant family effect observed by Ky et al. (2013) on CL. 


\section{Grafting season effects}

Season effect on CL formation was less evident than its previously recorded effects on nucleus retention rate and associated oyster mortalities (Ky et al, 2014a). Indeed, the pearl formation process takes several months of culture (24 months in this study), during which CL formation take place. This does not appear to occur during the early period of pearl culture, i.e. in the first 2-3 months after the graft operation. If it was the case, one would expect the month (season) of grafting, which was characterized by contrasting water temperature, to have a significant effect on CL formation. In our study, only graft operations in month 4 (April, at the beginning of spring season) produced a significantly different number of CL pearls in comparison to the other seasons (winter season: months 7, 8, 9; and autumn season: months10,11). Such a result could be related to the gonad sexual maturity, because it is here that the nuclei and mantle grafts are inserted. The Gambier archipelago is characterised by contrasting seasons with (1) the main natural spawning season in spring (October to December) and 2) synchronous oyster reproduction (Southgate and Lucas, 2008). During winter (July to September), energy is mostly directed to gametogenesis until spawning. So the relation between the gonad maturity and the presence of the saibo-nucleus may affect CL formation. Age of the recipient oysters could also be implicated as an "indirect seasonal effect" contributing to the result observed at month 4 . This age was quite different from the beginning (15 months old for the month 4 grafting) to the end of the 2010 experiments (nearly 2 years old for month 10 and 11), as the stock oysters was collected from November to December 2008. Some pearl farmers had already empirically observed more CL rate when using older oysters (farmers' pers. comm.). CL rate was also affected indirectly by month of graft, with grafting in autumn (April) more beneficial in this respect $(+13 \%)$, compared with winter (months $7,8,9)$ and spring (months 10,11). As a negative correlation exists between the amounts of RS and CL rates, the parameters which could affect seasonal variation in CL rate also affect RS rate. In addition, grafting in month 4 also clearly affects OT rates $(+24 \%)$, which could also be caused by the physiological, gonadal status and age of the recipient oysters, as for CL pearls. The effect on month of graft was greater for RT rate, than for CL, RS and OT (where only month 4 caused a significant difference). Environmental temperature seems to be one of the most important parameters affecting RT rate. The results showed significantly higher RT rates for the coldest $(8,9)$ and warmest $(11)$ months (with respectively $22^{\circ} \mathrm{C}$ and $28^{\circ} \mathrm{C}$ on average in the culture site - data not shown). For the intermediate months $(4,7$ and 10$)$, which have an average temperature of $25^{\circ} \mathrm{C}$, no significant effect was observed. 


\section{Conclusion}

Production of high quality cultured pearls, with less CL and more RS shapes is one of the main goals of every pearl farm. At the start of the pearl culture procedure, collaboration with experienced grafters was one of the most important factors affecting a pearl farm production. When a pearl farm technicians reached a high skill level, month of graft (season) was also an important factor influencing production. The present study was designed as a way to isolate grafter effects and month/ season of graft in a mono-site culture experiment. Grafter effect on CL, RS, OT and RT was significant, but less important than the effect of the month of grafting. Several factors could be the cause of this unexpected difference, such as the biological age of the oysters or their physiological status in relation to lagoon temperature. As the harvesting success rates and pearl quality are highly dependent on farm site, site-specific strategies must be designed to take these factors into account.

Our result in Mangareva growing site show that grafting in April, at the end of the hot season, should be integrated into annual schedules of pearl farms to improve rates of RS and decrease of CL and RT pearls. Investment in grafter skill improvement could also be realised for those showing poorer results at harvest time. At the scale of French Polynesia, where pearl culture is carried out in numerous grow-out sites, geographically distant and located over three archipelagos of atolls and islands (Gambier, Society and Tuamotu), a specific management production strategies must be built, site by site, by taking into account grafting during the most favourable period.

Acknowledgements. We would especially like to thank the host site and employees of Regahiga Pearl Farm (Mangareva Island - Gambier Archipelago - French Polynesia) for the generous support they provided. 


\section{References}

Akamatsu, S., 2003. Cultured pearl. Shinjyu Shinbun, Tokyo (in Japanese).

Blay, C., Sham-Koua, M., Vonau, V., Tetumu, R., Cabral, P., Ky, C.L., 2014. Influence of nacre rate on cultured pearl grade and colour in the black lipped pearl oyster Pinctada margaritifera using farmed donor families. Aquaculture International, 22 (2), 937-953.

Cartier, E.L. and Krzemnicki, M.S., 2013. New developments in cultured pearl production: use of organic and baroque shell nuclei. The Australian Gemnologist, 25 (1), 6-13.

Cartier, E.L., Krzemnicki, M.S., Ito, M., 2013. Cultured pearl farming and production in the Federated States of Micronesia. Gems and Gemnol., 48 (2), 108-122.

Caseiro, J., 1993. L'huître Perlière de Polynésie. Biominéralisation, Paramètres et Processus de Croissance, Effets Chromatiques dans la Coquille et dans la Perle de Pinctada Margaritifera. PhD thesis, University of Lyon, France, 386 pp.

Cochennec, N., Haffner, P., Levy, P., Saulnier, D., Fougerouse, A., Langy, S., 2006.

Development of an antiseptic procedure to improve retention rates during the grafting process of black-lip oyster, Pinctada margaritifera. World Aquaculture 37, 56-57.

Gauthier, J.-P., Gutierrez, G., Serrar, M., 2014. La "piqûre", un défaut à l'origine du cerclage de perles chez Pinctada margaritifera. Revue de Gemmologie A.F.G., 187, 6-8 (in French).

Haws, M., 2002. The Basic Methods of Pearl Farming: A Layman's Manual. Center for Tropical and Subtropical Aquaculture Publication No. 127, 79 pp.

Ito, M., 2009. Improving pearl quality by grafting and husbandry methods. Aqua Tips, 20 (1), $1-8$. 
Ito, M., 2011. Circle and spot formation mechanisms and changes in luster, color, and roundness of cultured pearls by grafting methods in Pinctada margaritifera. G\&G, Vol. 47, No. 2, p. 148, http://dx.doi.org/10.5741/ 10.5741/GEMS.47.2.79.

Joubert, C., Linard, C., Le Moullac G., Soyez, C., Saulnier, D., Teaniniuraitemoana, V., Ky, C.L., Gueguen, Y., 2014. Temperature and food influence shell growth and mantle gene expression of shell matrix proteins in the pearl oyster Pinctada margaritifera. PLoS ONE 9(8): e10394. doi:10.1371/journal.pone.010394.

Ky, C.L., Molinari, N., Moe, E., Pommier, S., 2014a. Impact of season and grafter skill on nucleus retention and pearl oyster mortality rate in Pinctada margaritifera aquaculture. Aquaculture International, in press DOI 10.1007/s10499-014-9774-6.

Ky, C.L., Blay, C., Sham-Koua, M., Lo, C., Cabral, P., 2014b. Indirect improvement of pearl grade and shape in farmed Pinctada margaritifera by donor oyster selection for green pearls. Aquaculture, 432, 154-162.

Ky, C.L., Blay C., Sham-Koua M., Vanaa V., Lo C., Cabral P., 2013. Family effect on cultured pearl quality in black-lipped pearl oyster Pinctada margaritifera and insights for genetic improvement. Aquatic Living Resource, 26, 133-145.

Le Pennec, M., Anastas, M., Bichet, H., Buestel, D., Cochard, J.C., Cochennec-Laureau, N., Coeroli, M., Conte, E., Correia, P., Fougerousse-Tsing, A., Langy, S., Le Moullac, G., Lo C., Peltzer, L., Pham, A., 2010. Huître Perlière et Perle de Tahiti. HQ Imaging, Faaa, French Polynesia.

McGinty, E.L., Evans, B.S., Taylor, J.U.U., Jerry, D.R., 2010. Xenografts and pearl production in two pearl oyster species, $P$. maxima and $P$. margaritifera: effect on pearl quality and a key to understanding genetic contribution. Aquaculture 302, 175-181.

McGinty, E.L., Zenger, K.R., Taylor, J.U.U., Evans, B.S., Jerry, D.R., 2011. Diagnostic genetic marker unravel the interplay between host and donor oyster contribution in cultured pearl formation. Aquaculture 304, 20-24. 
McGinty, E.L., Zenger, K.R., Jones, D.B., Jerry, D.R., 2012. Transcriptome analysis of biomineralisation-related genes within the pearl sac: host and donor oyster contribution. Marine Genomics, 5, 27-33.

Talvard, C., 2011. La perliculture en 2010. Points Forts de la Polynésie Française, No. 10, 8 pp.

Tayale, A., Gueguen, Y., Treguier, C, Le Grand, J., Cochennec-Laureau, N., Montagnani, C., Ky, C.L., 2012. Evidence of donor effect on cultured pearl quality from a duplicated grafting experiment on Pinctada margaritifera. using wild donors. Aquat. Living Resour. 25, 269280.

Murzyniec-Laurendeau, S., 2002. La Perle de Tahiti: La fin de la Crise. Master of Advance Studies thesis, University of French Polynesia, 125 pp.

Nava, M., Arizmendi, E., Farell, S., McLaurin, D., 2000. Evaluation of success in the seeding of round nuclei in Pteria sterna (Gould 1851), a new species in pearl culture. SPC Pearl Oyster Inf. Bull 14, 12-16.

Norton, J.H., John, S.L., Turner, I., Mayer, R.J., Newnham, R., 2000. Approaches to improve cultured pearl formation in Pinctada margaritifera through use of relaxation, antiseptic application and incision closure during bead insertion. Aquaculture 184, 1-17.

Ogimura, T., Futami, K., Katagiri, T.,Maita,M., Gonçalves, A.T., Endo, M., 2012. Deformation and blemishing of pearls caused by bacteria. Fish. Sci. 78, 1255-1262.

Southgate, P.C., Lucas J.S., 2008. The pearl oyster. In: Editors Southgate PC, Lucas JS. Elsevier

Wane, G., 2013. Les problèmes réels de l'industrie de la perle de Tahiti, Tahiti Pacifique, mensuel d'information et d'économie. 260: 15-24 
Wada, K., 1999. Shinjyunokagaku (Science of pearl). Shinjyu Shinbun, Tokyo (in Japanese). 
Fig. 1. Schema of the 6 graft experiments (indicated by the numbers 'graft \#4', 7, 8, 9, 10 and 11) performed during 2010 and the associated harvests made in 2012 . The graft number and harvest number (\#) correspond to the numbers of the month in the year. The number shown in brackets corresponds to the number of cultured pearls harvested. Each square correspond to a month and the blue and red colours to cold (autumn and winter) and hot (spring and summer) seasons.

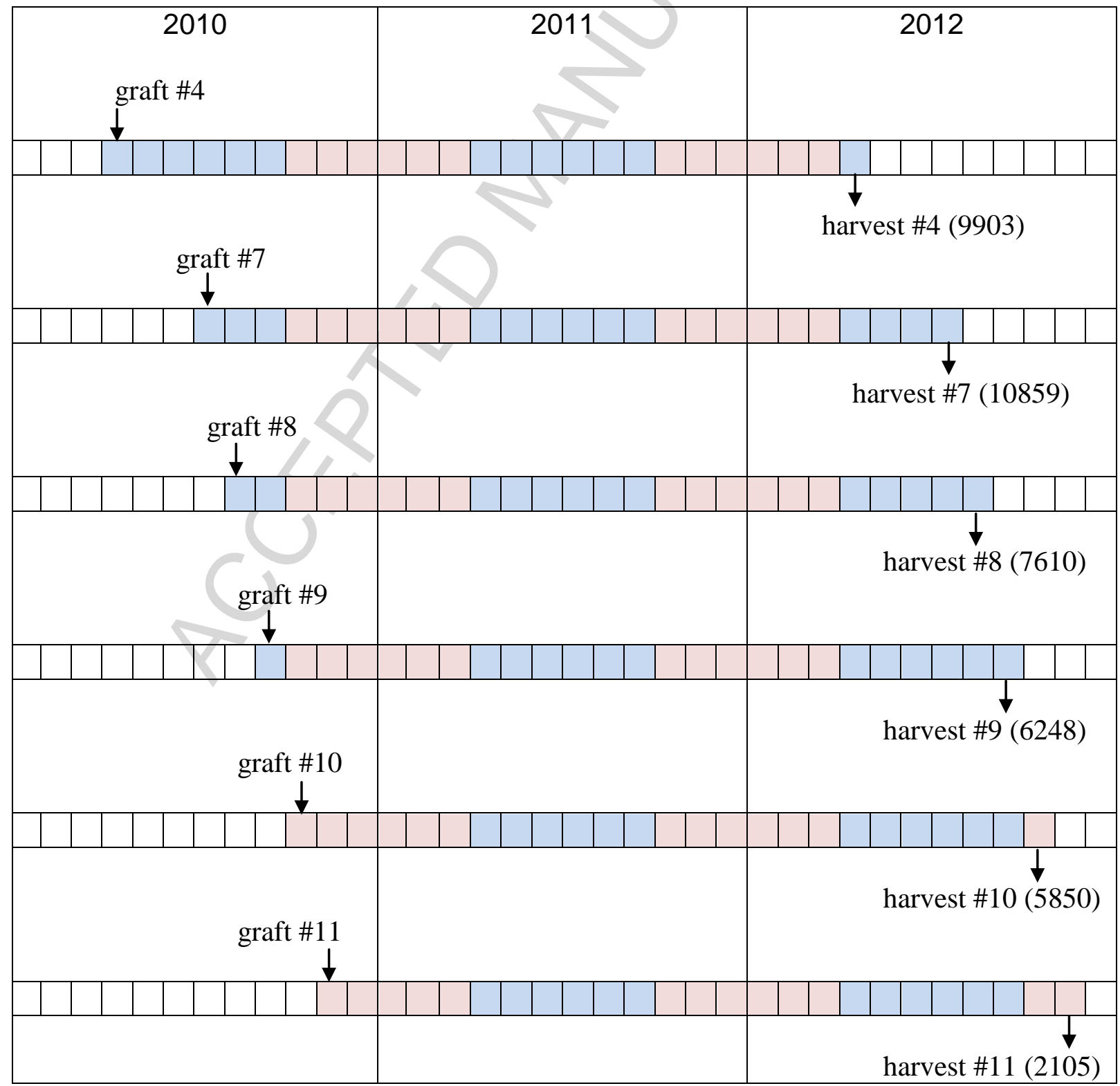


Fig. 2. Cultured pearl shape classes: "RS" (round or semi-round cultured pearls), "CL" (circled pearls), "OT" (other shapes, without any circles) and "RT" (reject/rebut pearls). Pictures of RS, CL and OT are harvest samples of high quality cultured pearls (grade A).

Photos by S. Nakasai, (c) S. Nakasai.

Cultured pearl shapes

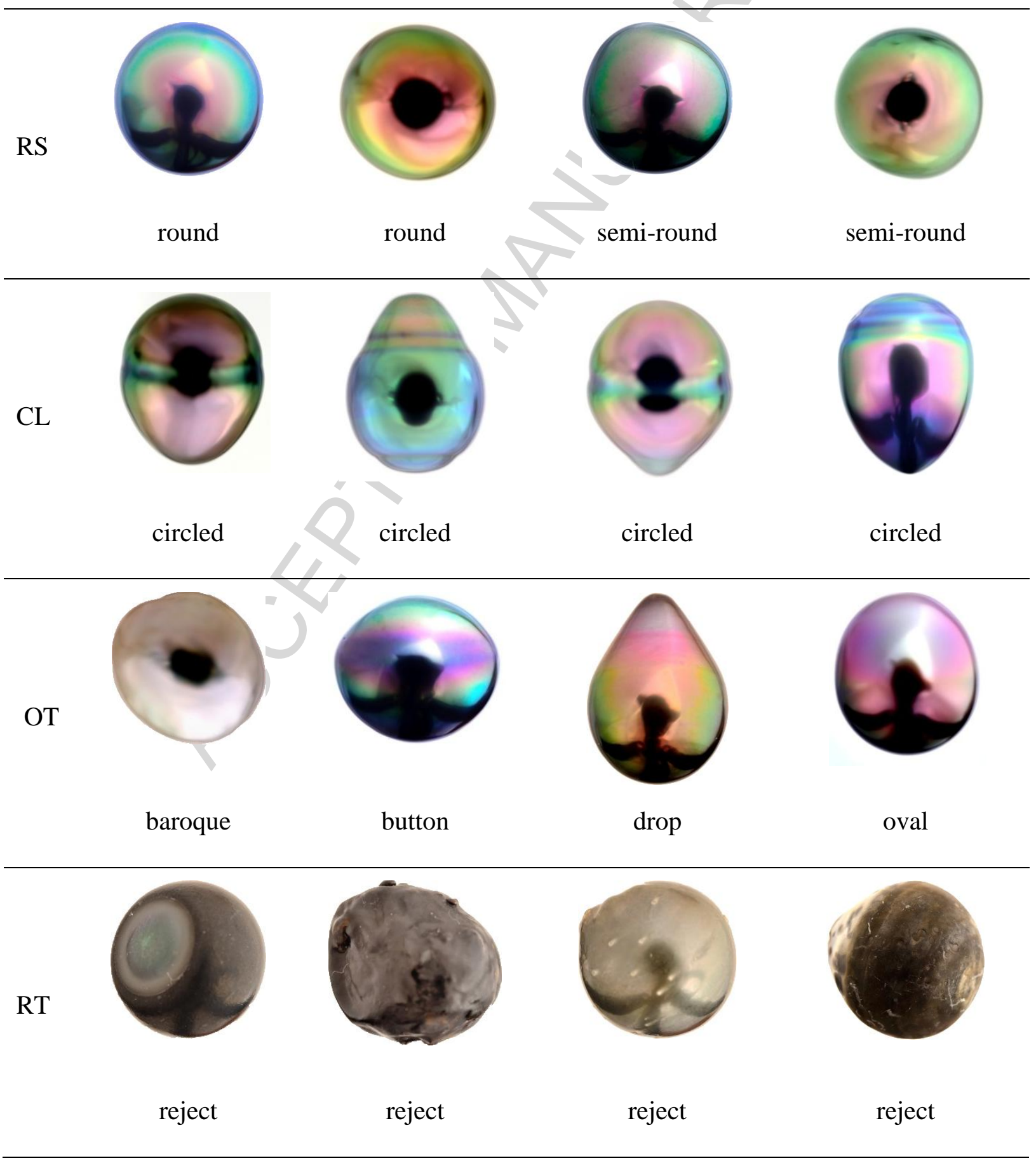


Fig. 3. Rates of circled (CL) round/semi round (RS), other shape (OT) and reject (RT) pearls (expressed in $\%$ of total harvested pearls) issued from grafting operations performed by the seventeen different grafters (indicated by the initials G, UM, MC, TC, EY, MD, MH, MM, GH, TARA, MAI, ME, AIU, F, TT, POE and MT) during 2010.
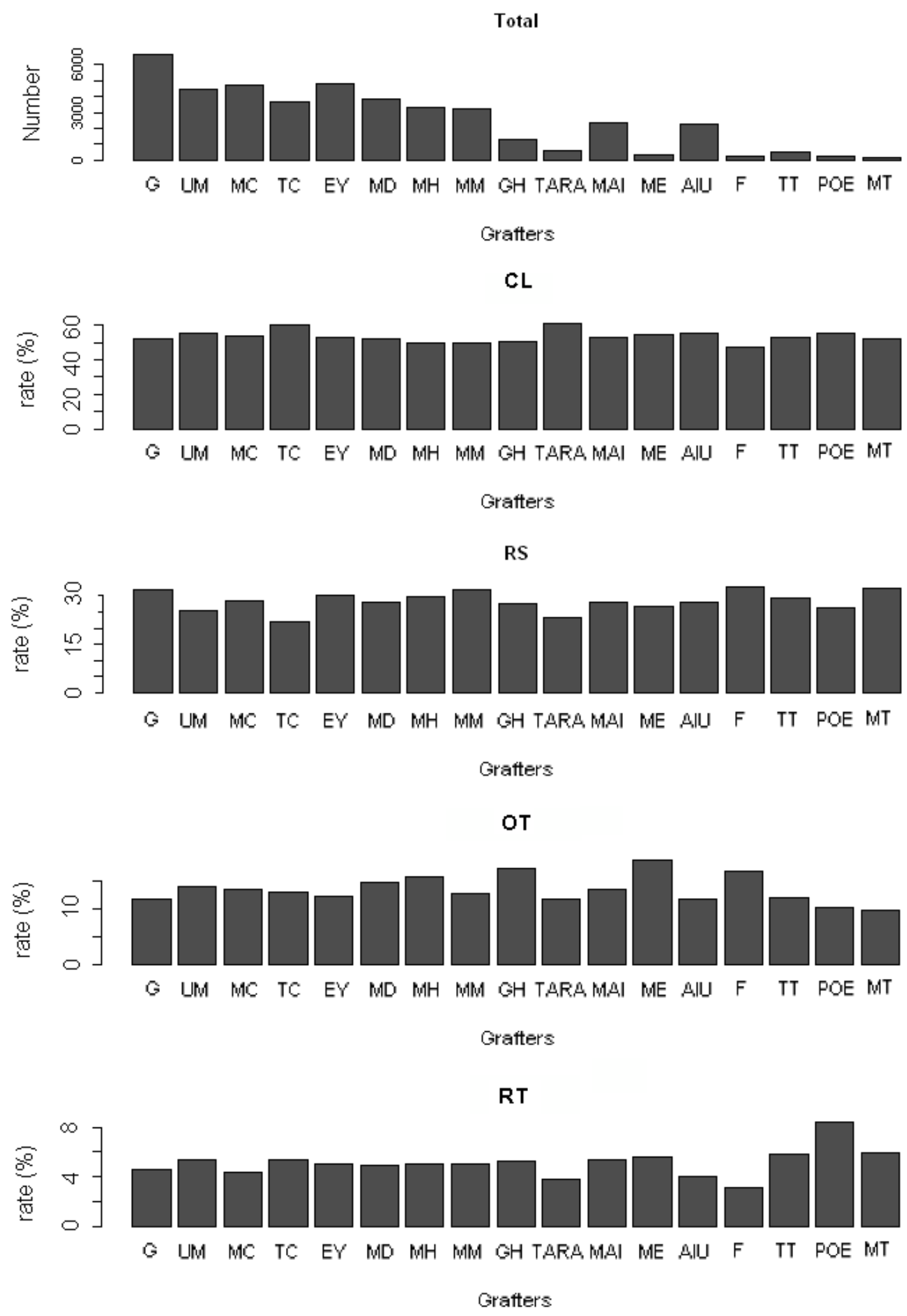
Fig. 4. Rates of circled (a) and round/semi-round (b) pearls, other shapes (c) and rebuts/rejects (d) issued from grafting operations performed by the 17 different grafters. Each box-plot has the following 4 elements: 1) mean (solid bar in the box-plot); 2) $25^{\text {th }}$ to $75^{\text {th }}$ percentile (rectangular box); 3) minimum and maximum values (extreme dots) and 4) outlier values (outside box whiskers). Means are taken across seasons, and data therefore include the variation of season of grafts. Data points significantly different from the other grafters at $p<$ 0.05 are indicated with an asterisk $(*)$.

a. Circled pearls

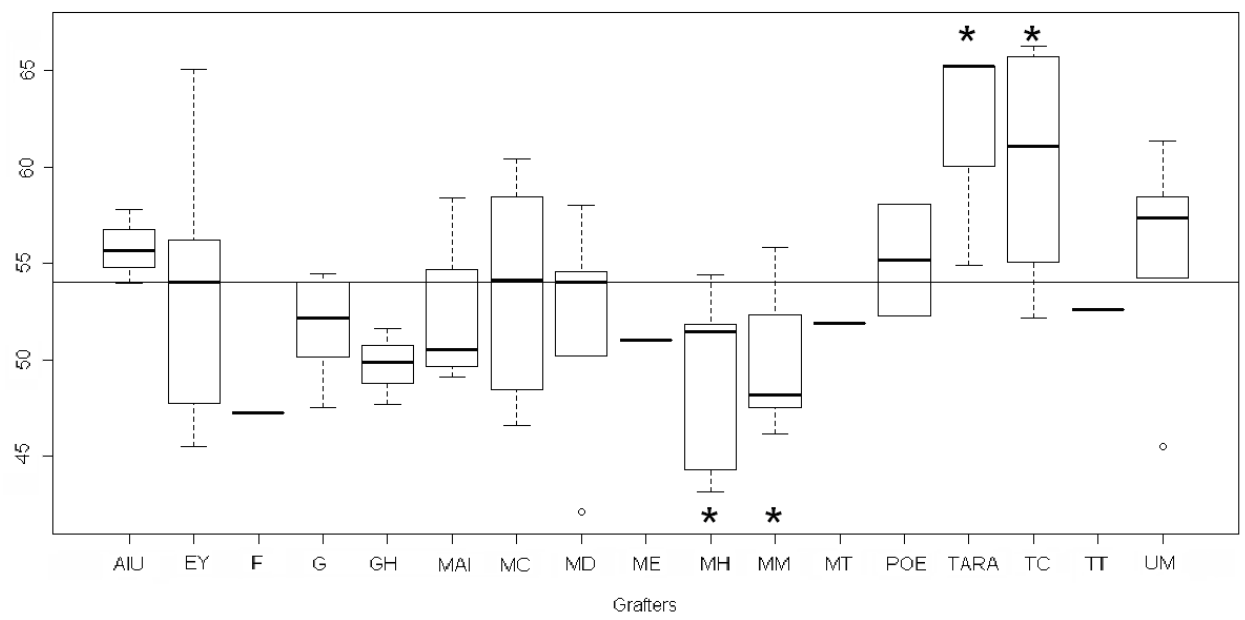

b. Round/semi-round pearls

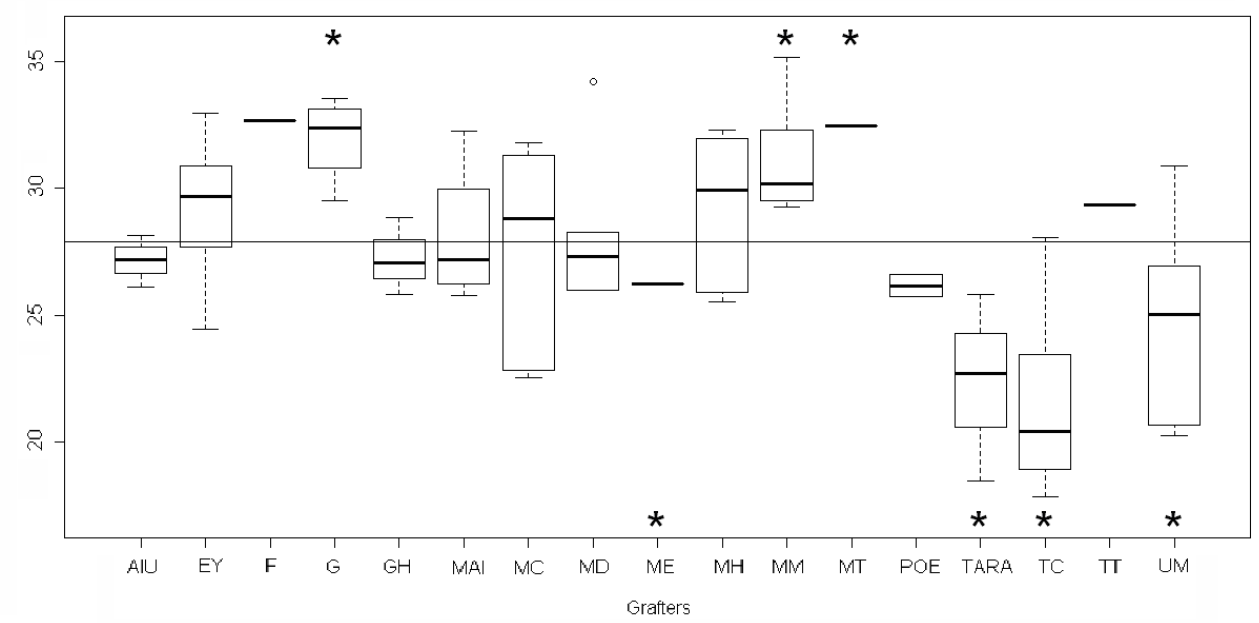


c. Other pearl shapes

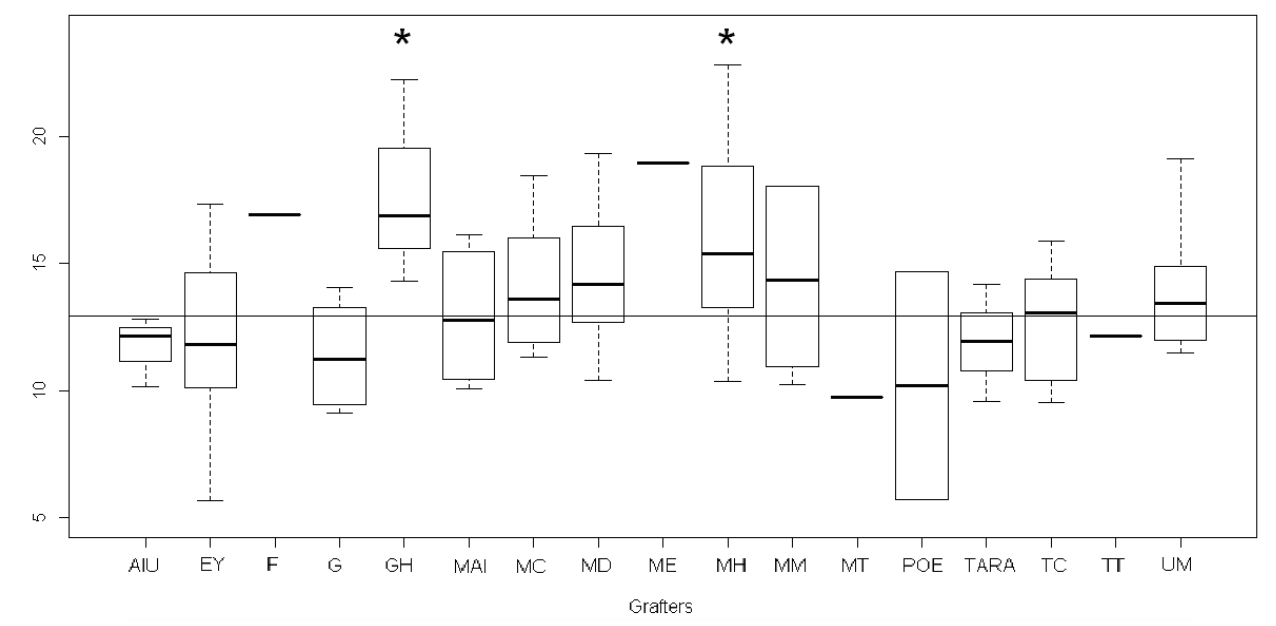

d. Reject pearls

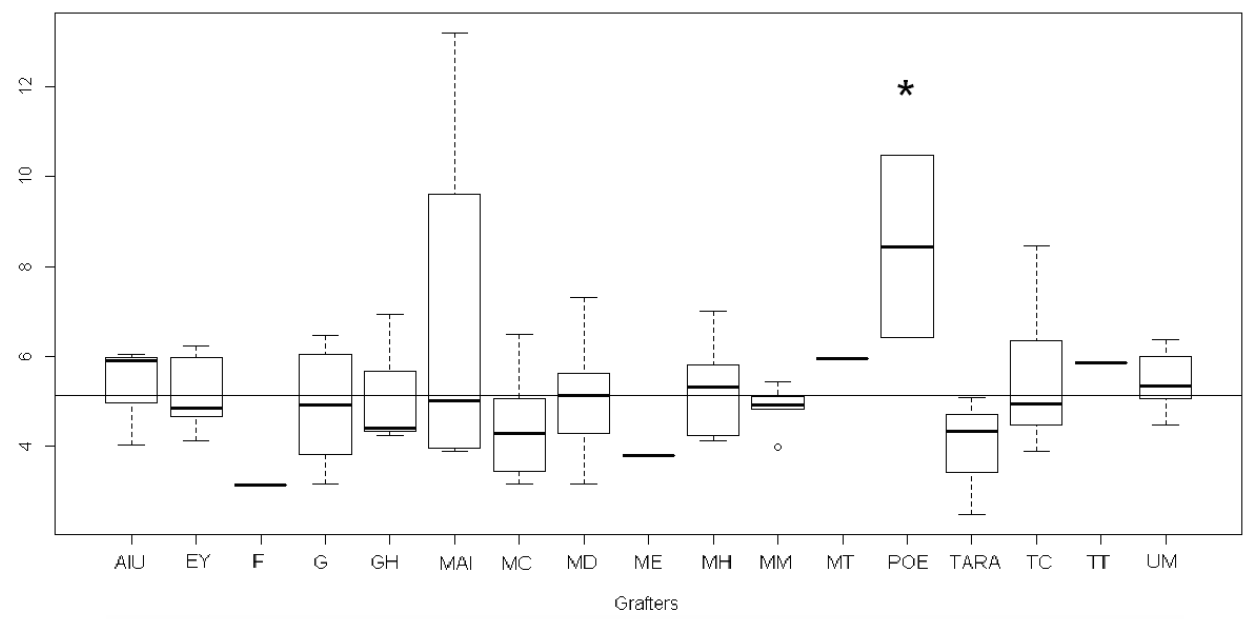


Fig. 5. Rates of circled (a) and round/semi-round (b) pearls, other shapes (c) and rebuts/rejects (d) according to month of graft. Each box-plot has the following 4 elements: 1) mean (solid bar in the box-plot); 2) $25^{\text {th }}$ to $75^{\text {th }}$ percentile (rectangular box); 3) minimum and maximum values (extreme dots) and 4) outlier values (outside box whiskers). Means are taken across grafters and data therefore includes the grafter effects. Data points significantly different from the other experiments at $p<0.05$ are indicated with an asterisk $(*)$.

a. Circled pearls

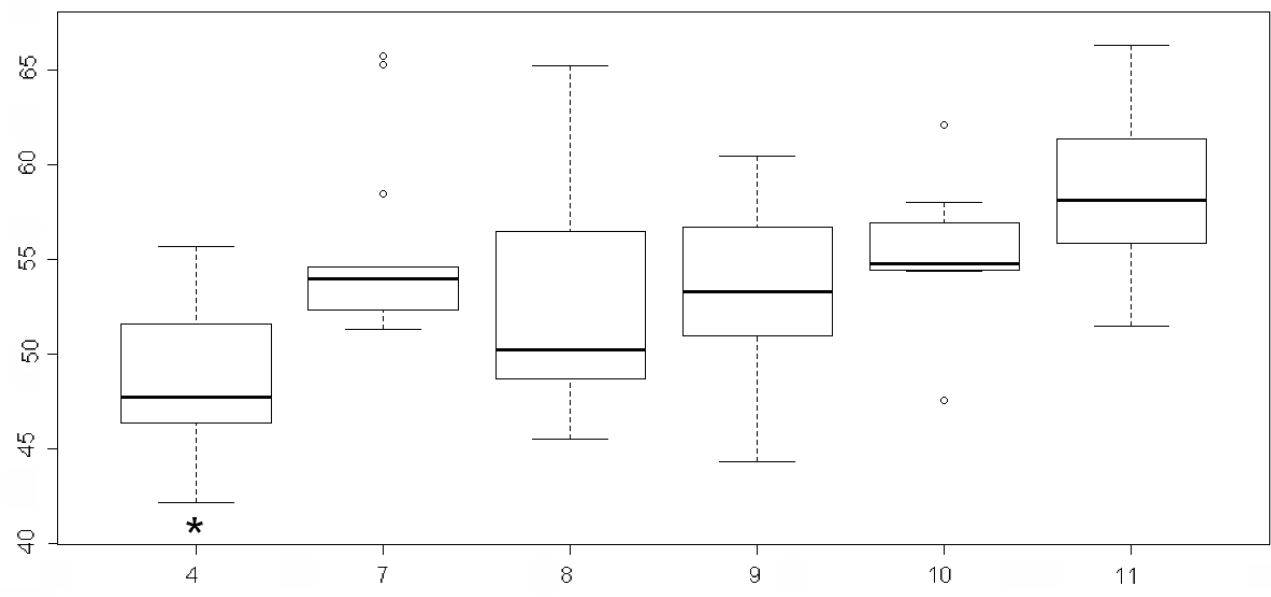

b. Round/ semi-round pearls

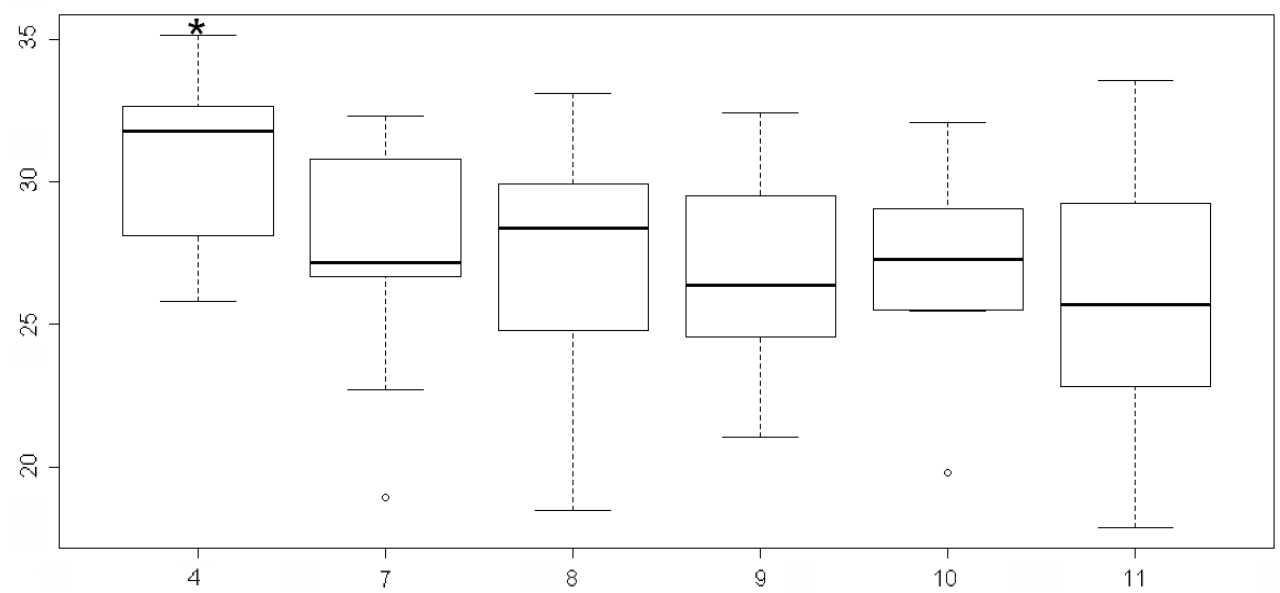


c. Other pearl shapes

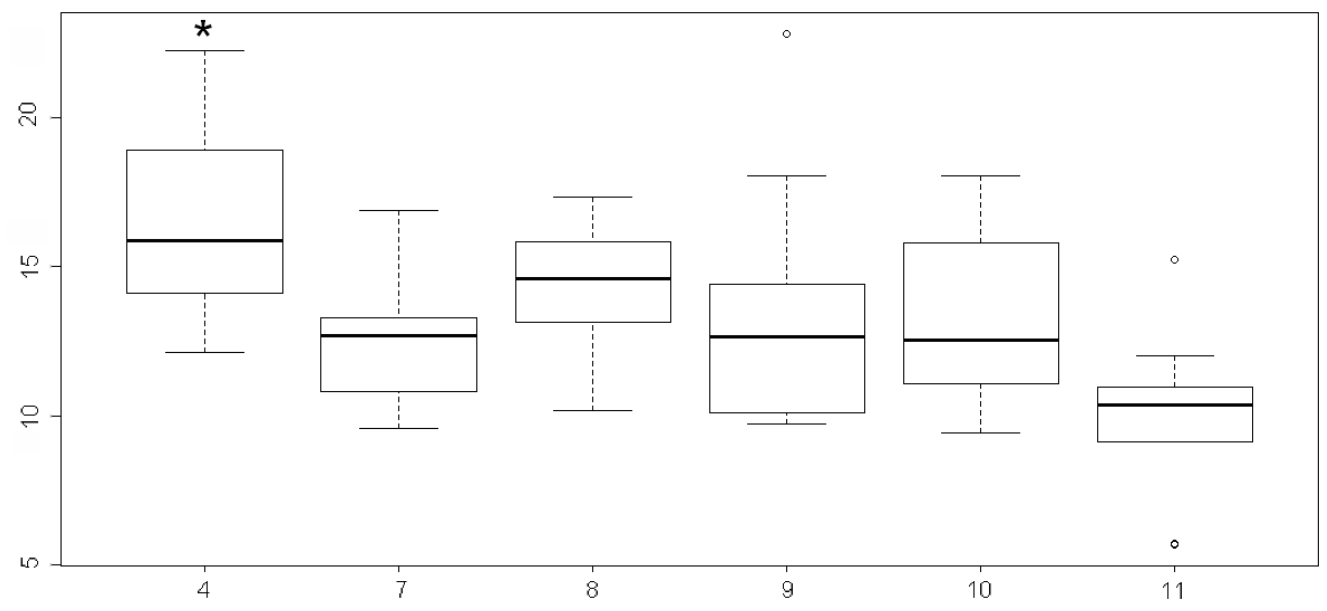

d. Reject pearls

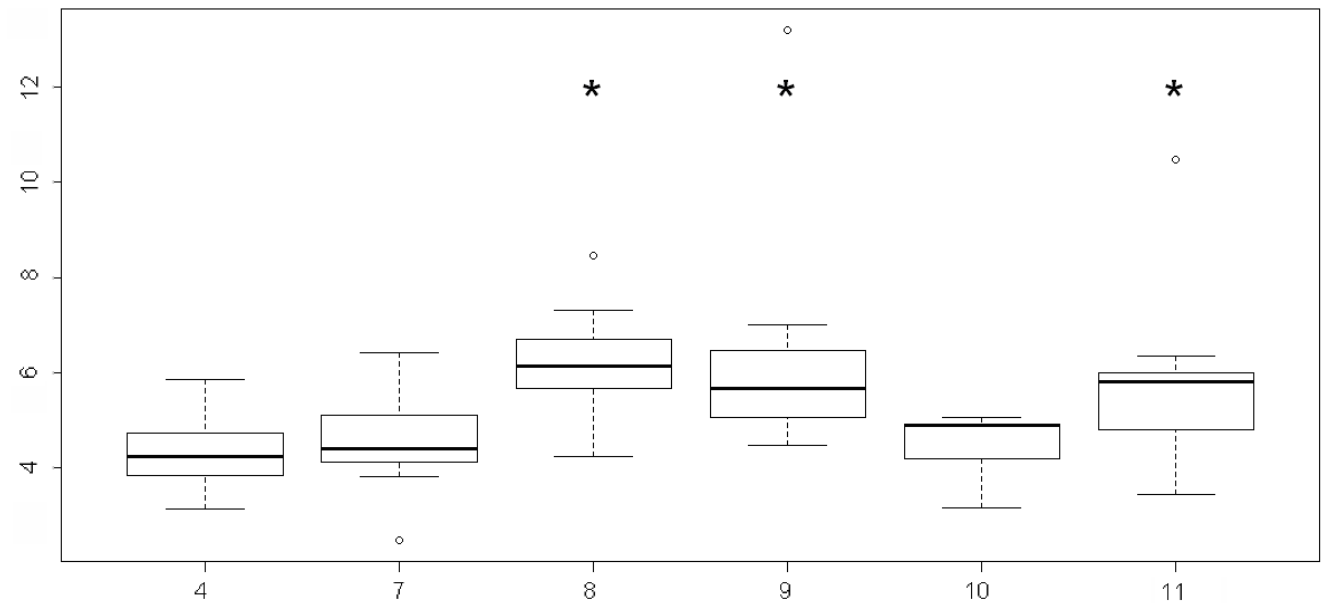


Table 1. Circled cultured pearls (\%) harvested following the 6 grafting experiments (indicated by the numbers $4,7,8,9,10$ and 11 given in the top row) and corresponding to each of the 17 grafters (initials given in the first column).

\begin{tabular}{|c|c|c|c|c|c|c|}
\hline & \multicolumn{6}{|c|}{ Graft experiments } \\
\hline & 4 & 7 & 8 & 9 & 10 & 11 \\
\hline $\mathrm{G}$ & 50.2 & 54.0 & 47.6 & 52.9 & 54.5 & 51.5 \\
\hline UM & 45.5 & 54.3 & 58.5 & 56.7 & 58.0 & 61.3 \\
\hline $\mathrm{MC}$ & 46.6 & 53.2 & 48.5 & 60.4 & 55.1 & 58.5 \\
\hline $\mathrm{TC}$ & 52.2 & 65.7 & 55.1 & 60.1 & 62.1 & 66.3 \\
\hline EY & 47.7 & 52.2 & 45.5 & 56.2 & 55.8 & 65.1 \\
\hline MD & 42.1 & 54.6 & 50.2 & 53.7 & 54.4 & 58.0 \\
\hline MH & 43.2 & 51.3 & 51.6 & 44.3 & 54.4 & 51.9 \\
\hline MM & 46.2 & 52.3 & 48.9 & 47.5 & 47.5 & 55.8 \\
\hline $\mathrm{GH}$ & 47.7 & 51.6 & 49.9 & - & - & - \\
\hline TARA & 54.9 & 05.4 & 65.2 & - & - & - \\
\hline MAI & 49.1 & 58.4 & 50.2 & 50.9 & - & - \\
\hline ME & 51.0 & . & - & - & - & - \\
\hline AIU & 55.7 & 54.0 & 57.8 & - & - & - \\
\hline $\mathrm{F}$ & 0. & - & - & - & - & - \\
\hline TT & & - & - & - & - & - \\
\hline POE & & 52.3 & - & - & - & 58.1 \\
\hline MT & & - & - & 51.9 & - & - \\
\hline Total & 48.4 & 54.7 & 51.3 & 55.7 & 56.2 & 58.1 \\
\hline
\end{tabular}


Table 2. Round and semi-round cultured pearls (\%) harvested following the 6 grafting experiments (indicated by the numbers $4,7,8,9,10$ and 11 given in the top row) and corresponding to each of the 17 grafters (initials given in the first column).

\begin{tabular}{|c|c|c|c|c|c|c|}
\hline & \multicolumn{6}{|c|}{ Graft experiments } \\
\hline & 4 & 7 & 8 & 9 & 10 & 11 \\
\hline $\mathrm{G}$ & 32.6 & 30.8 & 33.1 & 29.5 & 32.1 & 33.6 \\
\hline UM & 30.9 & 26.9 & 20.3 & 24.6 & 25.5 & 20.7 \\
\hline $\mathrm{MC}$ & 31.8 & 31.3 & 39.0 & 22.5 & 28.6 & 22.8 \\
\hline $\mathrm{TC}$ & 28.0 & 18.9 & 23.4 & 21.1 & 19.8 & 17.9 \\
\hline EY & 33.0 & 30.7 & 30.9 & 27.7 & 28.6 & 24.5 \\
\hline $\mathrm{MD}$ & 34.2 & 27.7 & 28.2 & 26.9 & 26.0 & 26.0 \\
\hline $\mathrm{MH}$ & 32.3 & 31.3 & 28.5 & 25.9 & 25.5 & 32.0 \\
\hline MM & 35.2 & 32.3 & 30.8 & 39.5 & 29.5 & 29.2 \\
\hline $\mathrm{GH}$ & 27.0 & 271 & 28.9 & - & - & - \\
\hline TARA & 25.8 & & 18.5 & - & - & - \\
\hline MAI & 32.2 & 26.7 & 27.7 & 25.8 & - & - \\
\hline $\mathrm{ME}$ & 26.2 & - & - & - & - & - \\
\hline AIU & 380 & 27.2 & 26.1 & - & - & - \\
\hline $\mathrm{F}$ & & - & - & - & - & - \\
\hline TT & & - & - & - & - & - \\
\hline POE & & 26.6 & - & - & - & 25.7 \\
\hline MT & - & - & - & 32.4 & - & - \\
\hline Total & 31.4 & 28.6 & 28.1 & 25.9 & 27.0 & 26.3 \\
\hline
\end{tabular}


Table 3. Other cultured pearl shapes (\%) harvested following the 6 experiments of graft (indicated by the numbers $4,7,8,9,10$ and 11 given in the top row) and corresponding to each of the 17 grafters (initials given in the first column).

\begin{tabular}{|c|c|c|c|c|c|c|}
\hline & \multicolumn{6}{|c|}{ Graft experiments } \\
\hline & 4 & 7 & 8 & 9 & 10 & 11 \\
\hline $\mathrm{G}$ & 14.1 & 11.4 & 13.3 & 11.1 & 9.4 & 9.1 \\
\hline UM & 19.1 & 13.5 & 14.9 & 13.3 & 11.5 & 12.0 \\
\hline $\mathrm{MC}$ & 18.5 & 11.3 & 16.0 & 12.0 & 11.9 & 15.2 \\
\hline $\mathrm{TC}$ & 15.9 & 10.4 & 13.0 & 14.4 & 13.2 & 9.5 \\
\hline EY & 14.6 & 13.0 & 17.3 & 10.1 & 10.7 & 5.7 \\
\hline MD & 19.3 & 12.7 & 14.2 & 14.1 & 16.5 & 10.4 \\
\hline MH & 18.8 & 13.3 & 15.7 & 22.8 & 15.1 & 10.4 \\
\hline MM & 13.8 & 10.2 & 14.9 & 18.0 & 18.0 & 11.0 \\
\hline $\mathrm{GH}$ & 22.2 & 16.9 & 14.3 & - & - & - \\
\hline TARA & 14.2 & & 12.0 & - & - & - \\
\hline MAI & 14.8 & .8 & 16.1 & 10.1 & - & - \\
\hline ME & 19.0 & 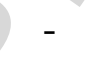 & - & - & - & - \\
\hline AIU & 121 & 12.8 & 10.2 & - & - & - \\
\hline $\mathrm{F}$ & 16 & - & - & - & - & - \\
\hline TT & & - & - & - & - & - \\
\hline POE & & 14.7 & - & - & - & 5.7 \\
\hline MT & & - & - & 9.7 & - & - \\
\hline Total & 16.0 & 12.2 & 14.3 & 12.6 & 12.3 & 10.2 \\
\hline
\end{tabular}


Table 4. Rebut/ Reject cultured pearls (\%) harvested following the 6 experiments of graft (indicated by the numbers $4,7,8,9,10$ and 11 given in the top row) and corresponding to each of the 17 grafters (initials given in the first column).

\begin{tabular}{|c|c|c|c|c|c|c|}
\hline & \multicolumn{6}{|c|}{ Graft experiments } \\
\hline & 4 & 7 & 8 & 9 & 10 & 11 \\
\hline $\mathrm{G}$ & 3.2 & 3.8 & 6.1 & 6.5 & 4.0 & 5.9 \\
\hline UM & 4.5 & 5.3 & 6.4 & 5.4 & 5.1 & 6.0 \\
\hline $\mathrm{MC}$ & 3.2 & 4.1 & 6.5 & 5.1 & 4.4 & 3.5 \\
\hline $\mathrm{TC}$ & 3.9 & 5.0 & 8.5 & 4.5 & 4.9 & 6.3 \\
\hline EY & 4.7 & 4.1 & 6.2 & 6.0 & 4.9 & 4.8 \\
\hline MD & 4.3 & 5.0 & 7.3 & 5.3 & 3.2 & 5.6 \\
\hline $\mathrm{MH}$ & 5.7 & 4.1 & 4.2 & 7.0 & 4.9 & 5.8 \\
\hline MM & 4.8 & 5.1 & 5.5 & 4.9 & 4.9 & 4.0 \\
\hline $\mathrm{GH}$ & 4.2 & 4 & 6.9 & - & - & - \\
\hline TARA & 5.1 & 2.5 & 4.3 & - & - & - \\
\hline MAI & 3.9 & & 6.0 & 13.2 & - & - \\
\hline ME & 3.8 & & - & - & - & - \\
\hline AIU & 4.0 & 6.0 & 5.9 & - & - & - \\
\hline $\mathrm{F}$ & & - & - & - & - & - \\
\hline TT & & - & - & - & - & - \\
\hline POE & & 6.4 & - & - & - & 10.5 \\
\hline MT & & - & - & 5.9 & - & - \\
\hline Total & 4.3 & 4.6 & 6.2 & 5.8 & 4.5 & 5.4 \\
\hline
\end{tabular}

